\title{
The influence of reservoir conditions on filtration parameters of shale rocks
}

\begin{abstract}
Pulse Decay apparatus enable measurement of shale formations reservoir permeability. For such type of pore space, permeability is not only a function of pore size distribution and porosity but also depends on pressure and temperature. Moreover, the type of flow varies as a function of pore radius in nano-pore range (Darcy flow, slip flow, diffusion). In this work, the impact of reservoir parameters on apparent permeability of the Polish shale rocks was discussed.
\end{abstract}

Key words: permeability, apparent permeability, reservoir and formation pressure, flow through nano-pores.

\section{Wpływ warunków złożowych na parametry filtracyjne skał łupkowych}

\begin{abstract}
Aparat Pulse Decay umożliwia pomiary parametrów filtracyjnych skał ze zbiornikowych formacji złożowych typu łupkowego. Dla przepływów w nanoporach (zakres średnic $d<100 \mathrm{~nm}$ ) przepuszczalność jest nie tylko funkcją parametrów przestrzeni porowej, lecz również takich parametrów jak ciśnienie i temperatura. Analiza przepływów dla przestrzeni nanoporowych pokazuje, że zmienia się mechanizm przepływu w zależności od rozkładu parametrów przestrzeni porowej (przepływ Darcy'ego, przepływ z poślizgiem, dyfuzja). W niniejszej pracy przeanalizowano wpływ i zmiany przepuszczalności pozornej w zależności od parametrów złożowych dla polskich skał łupkowych.

Słowa kluczowe: przepuszczalność, przepuszczalność pozorna, ciśnienie złożowe i ciśnienie górotworu, przepływ przez nanopory.
\end{abstract}

\section{Introduction}

Drilling, development and exploitation of shale type reservoirs have initially brought a number of surprising results. The permeability of shale formations was found to be 10 times higher than that of the permeability estimated by models. An analysis of all the elements affecting the flow of fluids through nano pore space allowed to correctly define the permeability of such formations. Javadpour and others [1,2] introduced the apparent permeability, as the parameter that includes the complexity of flow in nanopores. This parameter is very variable for the shale reservoirs and dependent on a series of parameters which do not affect the permeability of conventional rocks. The Pulse Decay apparatus (type PDP-250) enables measurement of this parameter. Nevertheless, in order to obtain a correct value of permeability, reservoir conditions must be simulated correctly.

This study is dedicated to the identification of parameters which have an impact on the value of the measured permeability and determination of the proper application of reservoir conditions during conducting measurements.

\section{Apparatus}

The apparatus for measuring the permeability by the PulseDecay method (type PDP-250, CoreLab) is used to examine the tight gas rocks, shale gas rocks and other rocks with very low permeability within the range from $10 \mathrm{nD}$ to $1 \mathrm{mD}$.
The schematic diagram shown in Figure 1 illustrates the PDP-250 system which consist of:

- an upstream test gas reservoir at volume $V_{1}$ and $V_{3}$,

- a downstream gas reservoir volume $V_{2}$ and $V_{4}$, 
- a high pressure core holder with Hassler type loading, which contains the sample (plug) with pore volume $V_{p}$,

- a differential pressure transducer to measure differential pressure $\Delta P$ - difference in pressure between the reservoirs $\left(P_{1}-P_{2}\right)$;

- a transducer to measure downstream pressure $P_{3}$.

As gas flows through the plug from the upstream reservoir, its pressure declines with time. Inversely, the gas flows into the downstream reservoir and its pressure increases with time. Therefore, flow rate can be determined from the known volume of each reservoir, fluid compressibility and the rate of pressure change. The momentary volumetric flow rate divided by the rate of pressure change is equal to the reservoir volume multiplied by the effective compressibility of the fluid and reservoir.

The resulting data is analyzed from the solution of the diffusivity equation derived from combining the differential form of Darcy equation with continuity equation.

In this study, Jones [3] technique was applied in which only a portion of the pulse decay curve, after smooth pressure gradient has been established, is investigated.

When the pressure decay curve in logarithmic scale $\ln [\Delta P(t)]$ is plotted versus time $(t)$ the decay clearly follows linear trend. This line can be fit by the following equation:

$$
\Delta P(t)=\Delta P_{0} e^{-m t}
$$

where:

$\Delta P(t)$ - value of differential pressure in a function of time,

$t \quad$ - time of pressure drop,

$\Delta P_{0}$ - initially set differential pressure,

$m-$ pressure pulse decay constant.

On this basis, the value of the pressure pulse decay constant $(m)$ of the test sample, which is equal to tangent of inclination angle of the linear trend, is determined from the formula (1) [11]:

$$
m=\frac{k A}{\beta V L \mu}
$$

where:

$k$ - permeability,

$A$ - cross section,

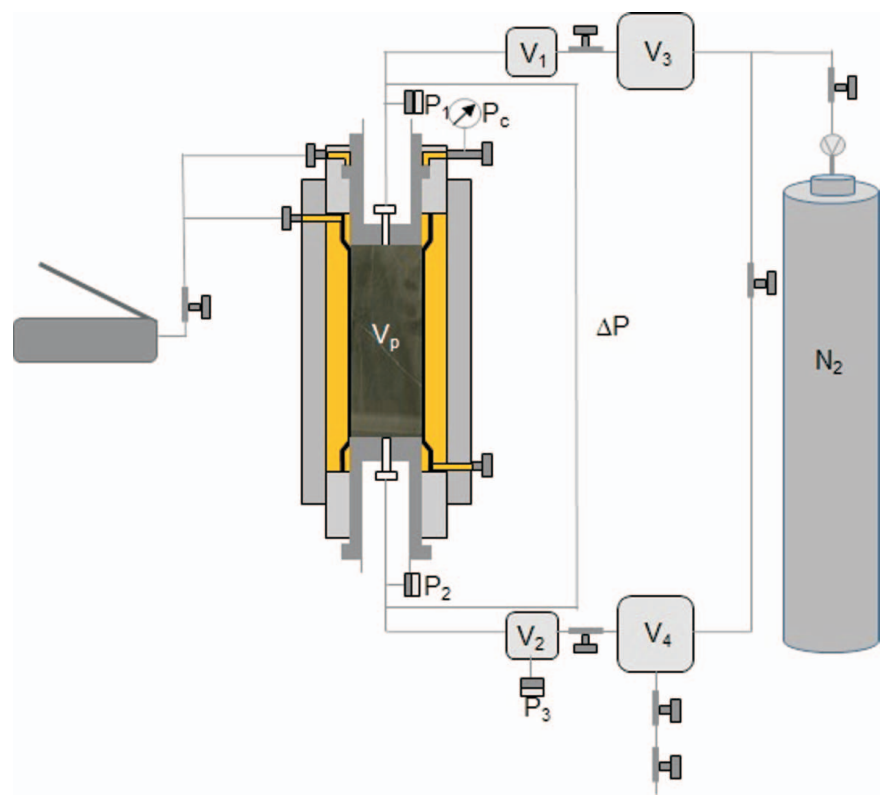

Fig. 1. Scheme of the apparatus for measurement of permeability PDP-250 Pulse Decay: $P c$ - confining pressure, $V p$ - pore volume, $\Delta P$ - differential pressure [6]

$\beta$ - compressibility of gas,

$\mu-$ viscosity of gas,

$V$ - volume of reservoirs,

$L$ - length of the sample.

In such established conditions the formula for the permeability $(k)$ is reduced to the form $(3)[3,11]$ :

$$
k=m \mu \beta \frac{L}{A} \cdot\left(\frac{V_{2} \cdot V_{1}}{V_{1}+V_{2}}\right)
$$

where:

$V_{1}$ - volume of upstream reservoir,

$V_{2}$ - volume of downstream reservoir.

The measurements of permeability analyzed in this study were done at room temperature on samples of Silurian shales from the Pomeranian basin.

The uncertainty in determination of permeability has been estimated based on the accuracy class of the measurement tools used. The estimated uncertainty of permeability measurement does not exceed $1.6 \%$.

\section{Physical foundations of the measurement method}

When the rocks with microporous formation of the pore space parameters are considered, all phenomena which may affect the flow rate must be taken into account. Generally, the Darcy flow dominates for pores with radii greater than $100 \mathrm{~nm}[7,8,9]$. The range of $100 \div 10 \mathrm{~nm}$ is the range of domination of the slip flow. Below $10 \mathrm{~nm}$ the processes associated with the diffusive flow begin to dominate. In shale rocks, taking into account their spatial variability, we are dealing with the simultaneous occurrence of all these processes and all of them must be considered in the permeability calculation. 
The general formula for the permeability value has been given by Javadpour [1,2]:

$$
k=\left[\sqrt{\frac{8 R T}{\pi M}\left(\frac{2}{2 R T \rho_{\text {avg }}}+\frac{\pi}{8 p_{\text {avg }}}\left(\frac{2}{\alpha}-1\right)\right) r \mu+\frac{r^{2}}{8}}\right]
$$

where:

$R$ - universal gas constant,

$T$ - absolute temperature,

$M$ - molar mass,

$\rho_{\text {avg }}$ - average gas density,

$p_{\text {avg }}-$ average gas pressure,

$\alpha$ - tangential momentum accommodation coefficient (equal numerically from 0 to 1 , where its value can be determined empirically, it is a function of surface smoothness, gas type, pressure, temperature and mass flow rate) [8],

$\mu$ - gas viscosity,

$r$ - pore radius.

By analyzing the equations (2) and (3) it is possible to determine the conditions which must be adhered to in order to obtain reliable permeability measurement.

1. In respect of the apparatus - measurement must be performed at a constant temperature and the sample may not change its volume during the whole measurement. It is also necessary, to determine correctly the dead volumes of the system (Figure 1).

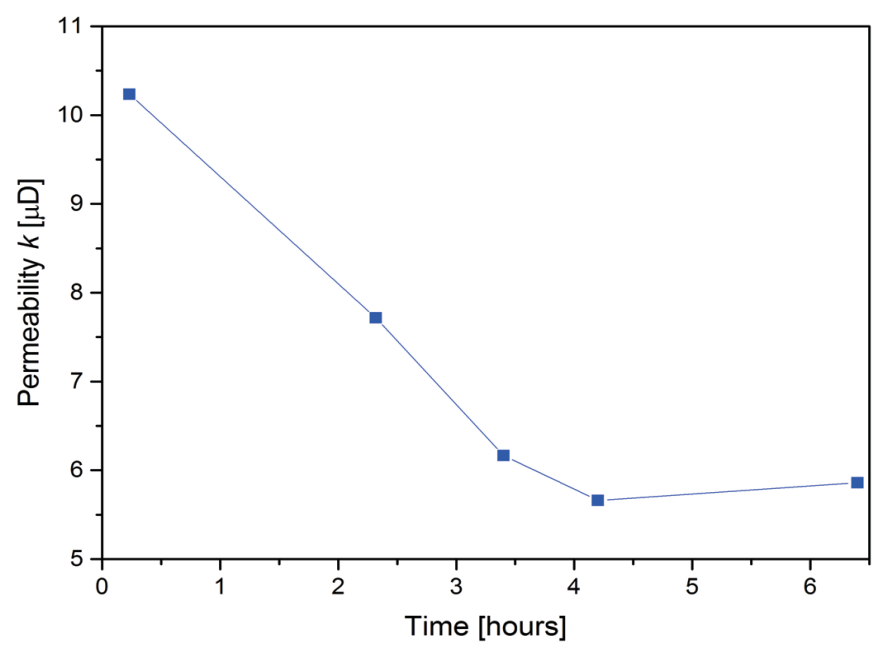

Fig. 2. Changes of permeability as a function of time from the moment of application of the confining pressure equal to overburden pressure to the sample examined

2. In respect of measurement conditions - the formula (3) indicates that permeability is a function of pore radii, temperature as well as overburden and reservoir pressure (both explicitly and in an entangled manner by the value $\alpha$ ) [8].

Summarizing, prior to conducting measurements it is necessary to check whether the test conditions are fulfilled and to investigate dependences of the measured permeability value on overburden pressure, reservoir pressure and effective stress (difference of overburden pressure and reservoir pressure).

\section{Experiments}

\section{Are rock samples from shale formations rigid bodies?}

It is a correct formulation of the physical problem: whether the samples retain the volume, shape and distribution of pores during measurement. Studies have unequivocally shown that they do not. Figure 2 shows results of studies of permeability for the selected sample as a function of time counted from the time of insertion of the sample into the apparatus. This effect occurred in all examined rocks (30 samples).

Thus, during the tests it is necessary to place the sample in the apparatus, apply the confining pressure $\left(P_{c}\right)$ which will be the equivalent of overburden pressure and wait until the sample will be stabilized in new conditions (i.e. two subsequent measurements of permeability should give the same result).

\section{Influence of overburden pressure}

In the Pulse Decay apparatus the overburden pressure is implemented by the confining pressure. The obtained results confirmed the evident dependence of the result on the overburden pressure. Generally it can be stated that pores compressibility increases with increasing overburden pressure. This effect is more pronounced in clay rich shales $[5,10]$.

Figures 3 and 4 show the dependences obtained for the sample with a fairly significant permeability and microfractures in the matrix (Figure 3) [4] and the sample with very low, purely intergranular permeability (Figure 4). Similar dependences in pressures for the samples containing fractures were shown by Miller et al [5].

The presence of microfractures in analyzed sample was indicated by permeability measurement as well as 2D X-ray images (Figure 5). The permeability of sample with microfracture $(k=4.36 \mu \mathrm{D})$ was one order of magnitude higher than that of purely intergranular permeability $(k=0.42 \mu \mathrm{D})$. The permeability value for that sample may thus be a reflection more of microfracture permeability than of matrix permeability.

The studies of the dependence of permeability and overburden pressure allowed, apart from the general dependence, 

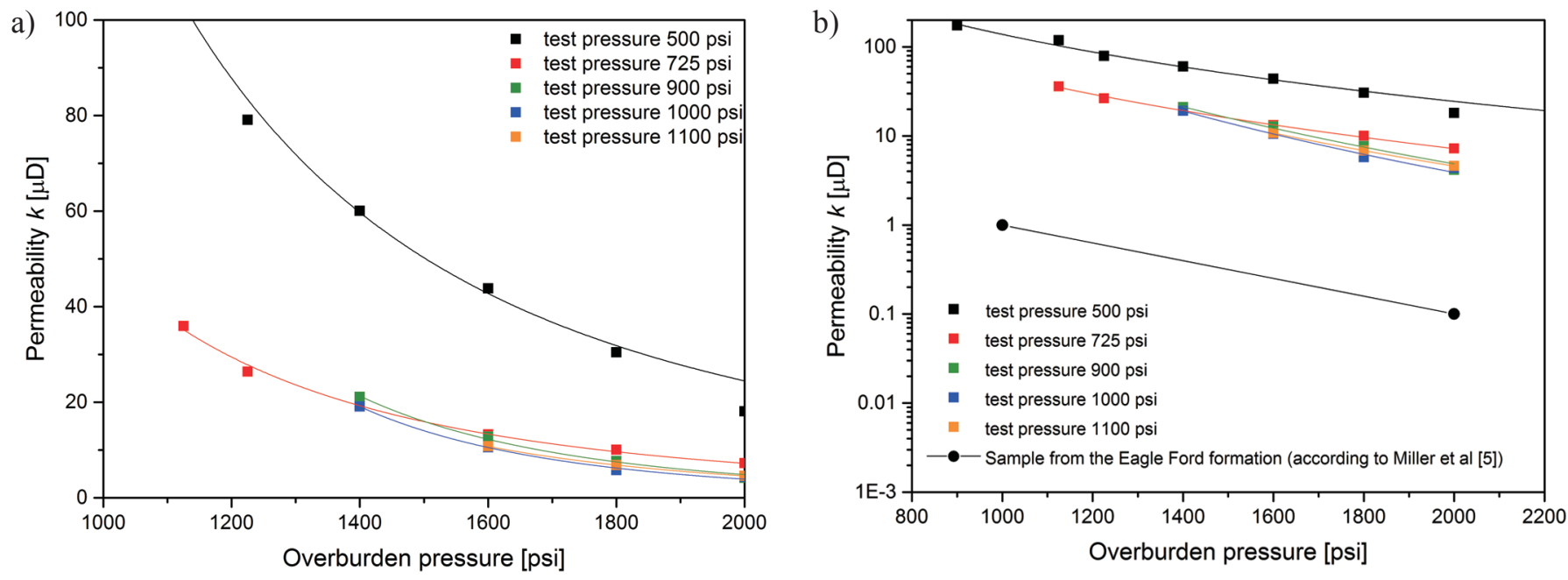

Fig. 3. Dependence of permeability values as a function of overburden pressure: a) sample with a nanofracture, b) comparison of the results received with values obtained by other laboratories for the sample with visible microfractures

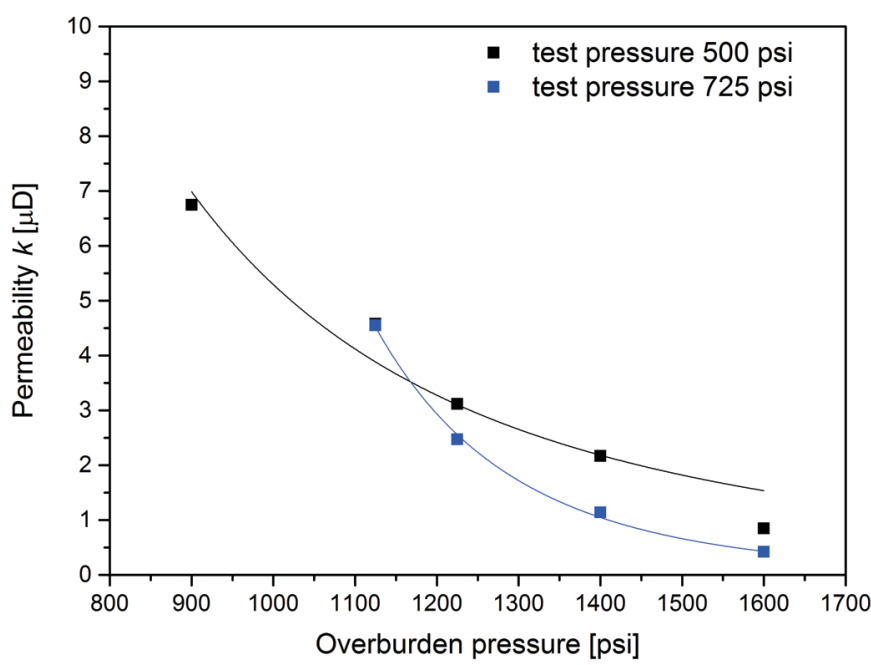

Fig. 4. Dependence of permeability as a function of overburden pressure (sample with low permeability, purely intergranular) to formulate also two conclusions. Firstly, with the increase of overburden pressure there is a decrease in its relative impact (Figure 6). Secondly, curves determined for different test pressures (i.e. apparatus analogs of reservoir pressure) intersect. This means that it is necessary to investigate also the dependence on reservoir pressure and the difference between these two values.

\section{Dependence on reservoir pressure}

In the apparatus the test pressure is the equivalent of reservoir pressure. The studies of the impact of reservoir pressure on permeability of shale rocks have confirmed the theories of flows in nanopores. Generally, the permeability decreases with the increasing reservoir pressure. These are the effects of turbulent flow and inertia. For the nano-space these effects are connected with molecular interactions (impact of the mean free path of particles and slippage effect). Figure 6 is the
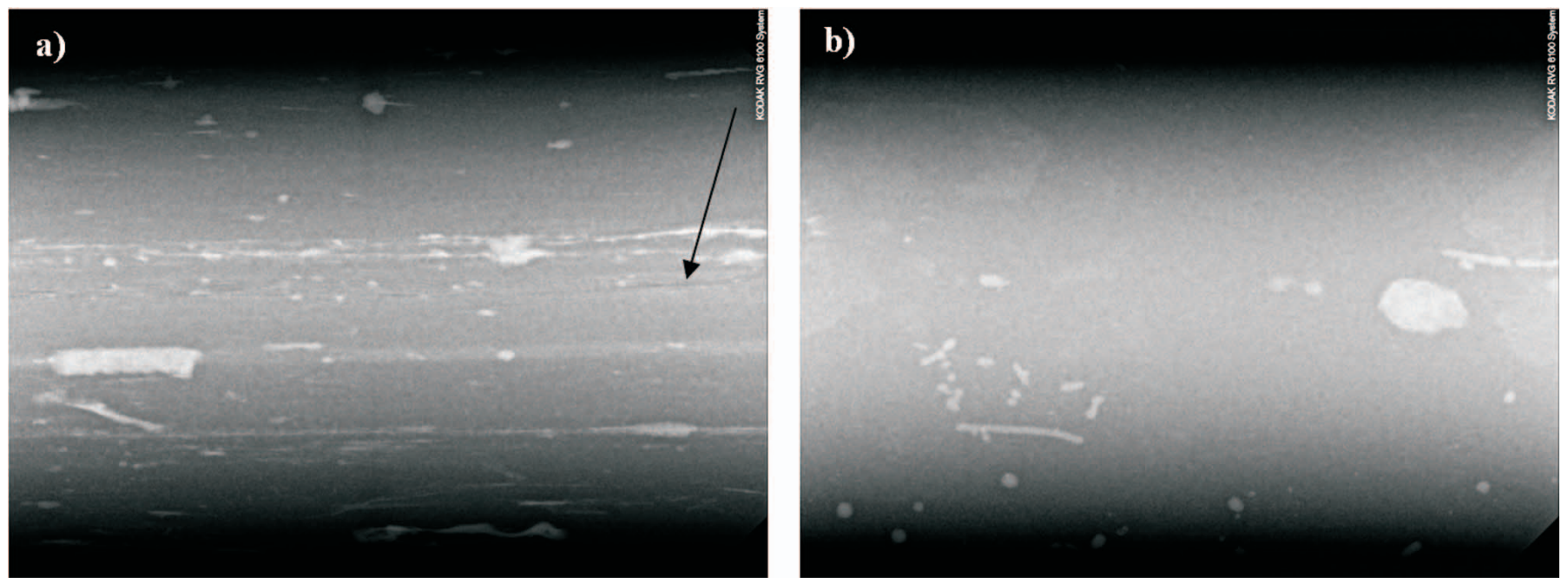

Fig. 5. 2D X-ray images of sample with microfracture a) and sample with purely intergranular permeability b). The arrow indicate microfracture. Density variations are shown in a grey scale - less dense regions have relatively darker appearance. 
illustration of these effects for the sample with microfractures, whereas Figure 7 shows the changes of permeability for the sample with a very low value of this parameter.

When the dependence of the permeability on reservoir pressure is analyzed, the effect of different mechanisms of fluid flowthrough the pore space need to be investigated. Hence, there is the possibility of finding the distinct boundaries separating the individual flow mechanisms.

Permeability variation in a function of reservoir pressure raises the question about the scale of variability of this parameter for the constant value of the overburden pressure. Curves of the maximum and minimum permeability values for a given value of effective stress are shown in a Figure 8. The differences are significant and they decrease with the increasing differential pressure and overburden pressure.

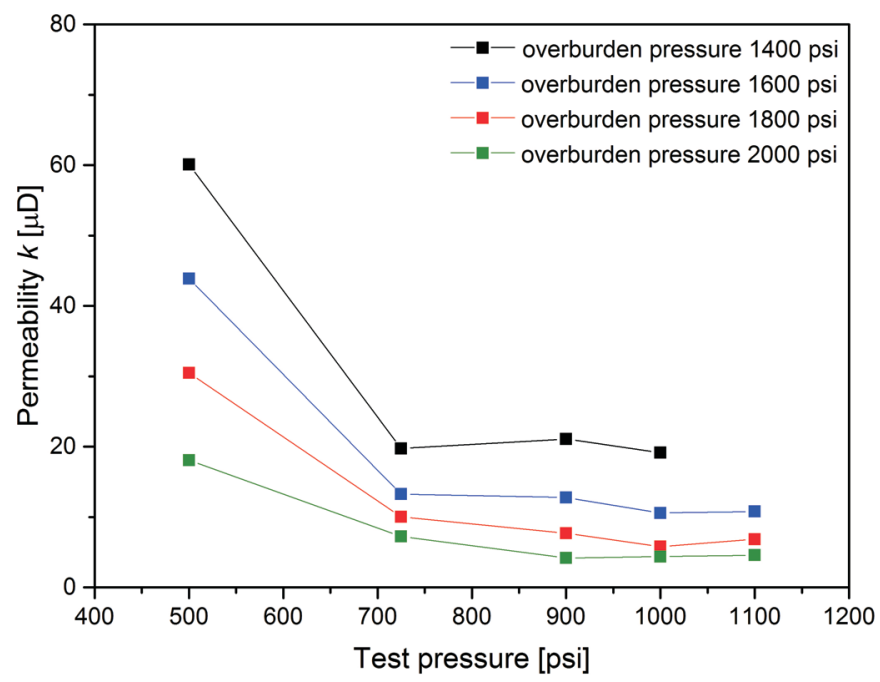

Fig. 6. The dependence of permeability values on reservoir pressure for the sample with nanofractures

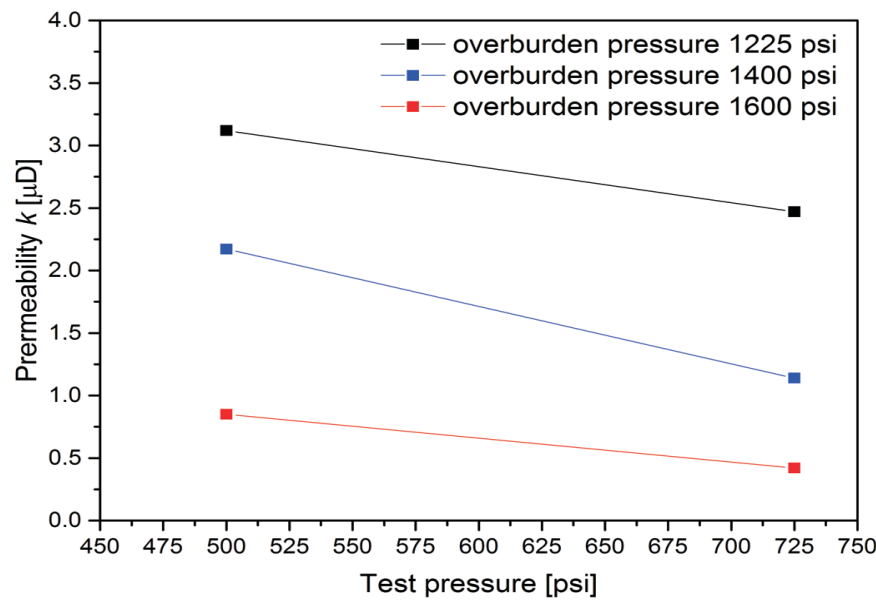

Fig. 7. The dependence of the permeability values on reservoir pressure for the sample with nanopores

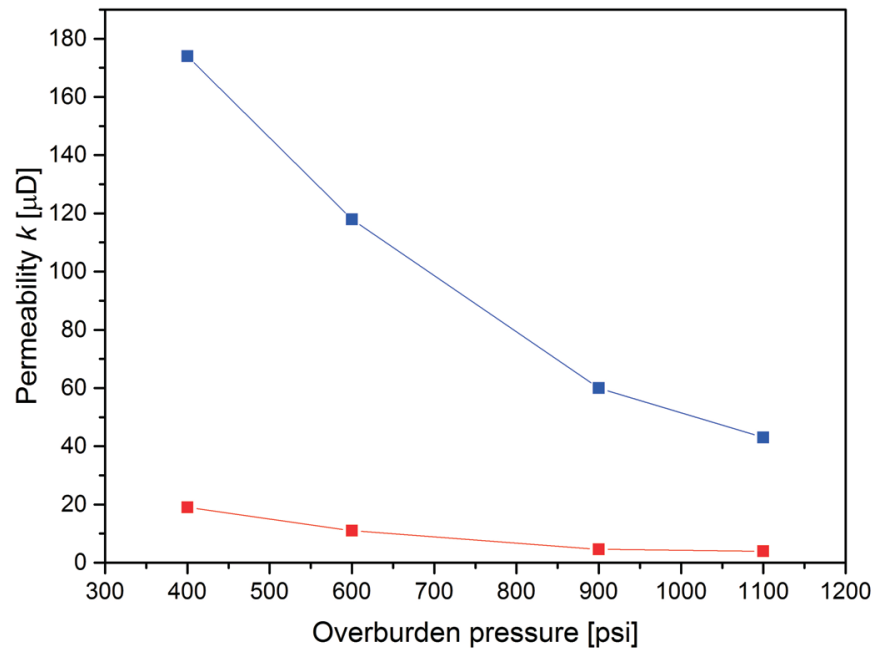

Fig. 8. The values of permeability as a function of the overburden pressure values (red curve - minimum values, blue curve - maximum values)

\section{Summary}

The conducted studies have confirmed the extremely complex dependences in variability of permeability values (especially for the overburden pressures below 2000 psi and reservoir pressures below $1300 \mathrm{psi}$ ). This is the result of superposition of the change in the flow mechanism as a function of pore sizes and the compression of pore space caused by the overburden pressure. Decreasing of relative differences in the observed phenomena together with increasing overburden pressure is the effect of shale rocks compression, so that asymptotically their permeability approaches zero.
Summarizing:

- reliable permeability measurements of rocks from shale formations require the initial stabilization of the test sample at the reservoir overburden pressure,

- measurement must take place in reservoir conditions, which means in this case the simulation of overburden pressure, reservoir pressure and reservoir temperature.

- conducting measurements without taking into account any of above mentioned parameters may cause relative errors reaching several hundred percent.

Please cite as: Nafta-Gaz 2015, no. 11, p. 827-832, DOI: 10.18668/NG2015.11.03

Article contributed to the Editor 31.08.2015. Approved for publication 30.09.2015.

The article is the result of research conducted in connection with the project: The methodology for determining sweet spots on the basis of geochemical, petrophysical, geomechanical properties based on the correlation of laboratory test results with geophysical 
measurements and 3D generating model, co-funded by the National Centre for Research and Development as part of the programme BLUE GAS - POLISH SHALE GAS. Contract No. BG1/MWSSSG/13.

\section{Literature}

[1] Javadpour F., Fisher D., Unsworth M.: Nanoscale gas flow in shale gas sediments. Journal of Canadian Petroleum Technology 2007, vol. 46, no. 10, pp. 55-61.

[2] Javadpour F.: Nanopores and Apparent Permeability of Gas Flow in Mudrocks (shales and Siltstones). Journal of Canadian Petroleum Technology 2009, vol. 48, no. 8, pp. 16-21.

[3] Jones S. C.: A Technique for Faster Pulse-Decay Permeability Measurements in Tight Rocks. Journal SPE Formation Evaluation 1997, vol. 12, pp. 19-26, DOI: 10.2118/28450-PA.

[4] Leśniak G.: Estimating of aperture microfracture in shale rocks. Nafta-Gaz 2015, no. 11, pp. 840-846

[5] Miller R. S., Conway M., Salter G.: Pressure-Dependant Permeability in Shale Reservoirs Implications for Estimated Ultimate Recovery. AAPG Hedberg Conference, 2-5 December 2010, Austin, Texas.

[6] Pulse Decay Permeameter (PDP-250) Operations Manual.

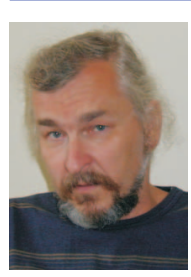

Prof. dr hab. Piotr Such

Assoc. Professor

Deputy Director

Exploration of Hydrocarbons

Oil and Gas Institute - National Research Institute

ul. Lubicz 25 A, 31-503 Kraków

E-mail: piotr.such@inig.pl

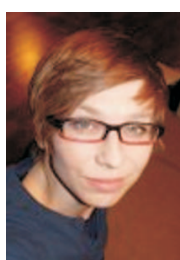

Maja MROCZKOWSKA-SZERSZEŃ Ph.D., Eng. Assistant Professor at Geology and Geochemistry Department

Oil and Gas Institute - National Research Institute

ul. Lubicz 25 A

31-503 Kraków

E-mail:maja.mroczkowska@inig.pl
[7] Shabro V., Torres-Verdin C., Javadpour F.: Numerical Simulation of Shale-Gas Production: from Pore-Scale Modeling of Slip-Flow, Knudsen Diffusion and Langmuir Desorption to Reservoir Modeling of Compressible Fluid. SPE 144 355, 2011.

[8] Such P.: Przeplyw gazu przez nanopory - proba oceny. Nafta-Gaz 2014, no. 10, pp. 671-675.

[9] Such P.: Przestrzen porowa skal lupkowych. Nafta-Gaz 2012, no. 9, pp. 558-561.

[10] Sutherland H. J., Cave S. P.: Argon gas permeability of New Mexico rock salt under hydrostatic compression. International Journal of Rock Mechanics and Mining Sciences \&Geomechanics 1980, Abstr. 17, pp. 281-288.

[11] Zhang X., Spiers C., Peach C.: Tight Rock Permeability Measurement By Pressure Pulse Decay and Modeling. Scaweb. Org. 2013, pp. 1-12 (http://www.scaweb.org/assets/papers/2013_papers/SCA2013-010.pdf).

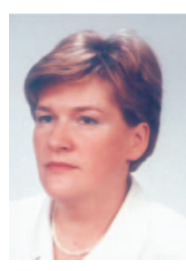

Lidia DUDEK M.Sc. Eng.

Senior Technical Research Specialist

Department of Geology and Geochemistry

Oil and Gas Institute - National Research Institute

ul. Lubicz 25 A

31-503 Kraków

E-mail:dudekl@inig.pl

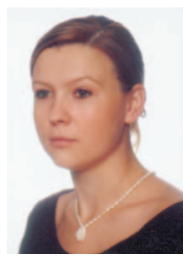

Renata CICHA-SZOT M.Sc. Eng.

Junior Scientist

Department of Petroleum Engineering

Oil and Gas Institute - National Research Institute

ul. Lubicz 25 A

31-503 Kraków

E-mail: cicha@inig.pl 